12689233/Use_of_Comics_Manga_as_a_Learning_Tool_to_Teach_Translatio n_of_Japanese._JLTL_Vol.3_No.2 (дата звернення 23.12.2021)

2.【マンガ教材】日本語教育の授業に漫画を取り入れるアイデア URL: https://edujapa.com/mikke/level/1/mangainclass/ (дата звернення 23.12.2021)

DOI https://doi.org/10.30525/978-9934-26-180-0-53

\title{
ЕФЕКТИВНІ МЕТОДИ НАВЧАННЯ АНГЛІЙСЬКОЇ МОВИ У СУЧАСНІЙ ШКОЛІ
}

\author{
Толкова Т. М. \\ кандидат педагогічних наук, \\ незалежний дослідник
}

м. Кам'янецьь-Подільський, Хмельницька область, Украӥна

Актуальними завданнями сучасної школи є розвиток та формування творчої особистості, пошук ефективних шляхів навчання, розвиток пізнавальних інтересів дитини, підвищення мотивації до вивчення мови. Як показує практика, за останні роки, суттєво змінюються підходи до викладання англійської мови у школах. Традиційні методи втрачають свої позиції в порівнянні з новими, інноваційними, цікавими та сприйнятливими для дітей методами викладання англійської мови.

Вивченню інтерактивних методів навчання та виховання у системі освіти присвячені праці А. Алексюка, І. Балицької, Т. Бичківської, О. Вєтохова, М. Кларіна, Ю. Кузнецової, Л. Пироженко, О. Пометун, В. Редька, С. Шевченка.

Сутність інтерактивного навчання у тому, що навчальний процес відбувається за умов постійної, активної взаємодії всіх учнів. Це співнавчання, взаємонавчання (колективне, групове, навчання у співпраці), де i учень, і вчитель $є$ рівноправними, рівнозначними суб'єктами навчання, розуміють, що вони роблять, рефлексують 3 приводу того, що вони знають, вміють і здійснюють. Організація інтерактивного навчання передбачає моделювання життєвих ситуацій, використання рольових ігор, вирішення проблеми на основі аналізу обставин та відповідної ситуації [3, с. 7].

На уроках англійської мови для передачі навчальної інформації найчастіше використовується лекційний метод навчання (lecture). 
Подання навчального матеріалу в лекційній формі $є$ основою для різних видів наступної навчальної діяльності. Для кращого засвоєння матеріалу використовують аудіо- і відеозасоби. 3 метою оптимізації навчального матеріалу після завершення лекції проводяться короткі обговорення. Недоліками методу є домінуюча роль вчителя в процесі комунікації $\mathrm{i}$ відповідна пасивність учнів. Метод не враховує індивідуальних особливостей дітей, які краще сприймають матеріал іншими способами та не дає можливості вчителю оцінити ефективність своєї роботи. Навіть добре підготовлена, цікава та зрозуміла лекція не навчить дітей думати самостійно. Щоб привернути увагу дітей до запропонованої теми, викликати жвавий інтерес і бажання аудиторії обговорити почуте, лекцію варто розпочинати з дискусійного запитання.

Дискусії (discussions) - обговорення, формують стосунки між дітьми та сприяють кращому засвоєнню навчального матеріалу. Дискусії $\epsilon$ засобом досягнення комунікативних цілей навчання, розвивають у дітей уміння пояснювати власну точку зору. Різновидами дискусії є «мозковий штурм» (brainstorming) та «шумні групи» (buzz groups). «Мозковий штурм» - ефективний метод колективного обговорення, пошуку рішень, що спонукає учасників розвивати уяву, виявляти творчість шляхом вільного висловлювання думок і допомагає знаходити декілька варіантів вирішення конкретної проблеми. У результаті проведення мозкового штурму відбувається обмін ідеями та думками, стимулюється розвиток нових ідей та думок. «Шумні групи» сприяють кращому розумінню дітьми однієї конкретної теми, проблеми чи підходу до розв'язання певної ситуації. Метод використовується у малих групах і $\epsilon$ механізмом здійснення глибокого аналізу певної проблеми чи теми.

Варто відзначити ефективність творчих, письмових робіт у вивченні англійської мови, які допомагають більш чітко осмислювати навчальний матеріал на відміну від звичайного читання. Письмова робота або проект (project) вимагає повної уваги до змісту ідей, до вибору мовних засобів, логічної послідовності аргументів. Письмова робота допомагає краще запам'ятати й інтерпретувати матеріал, тому що під час перевірки написаного тексту відбувається поглиблене переосмислення інформації, іiі узагальнення й виявлення сутнісних зв'язків між окремими змістовими елементами.

Важливим методом у навчанні англійської мови є метод проектів. Проект - результат самостійної роботи дитини, який спрямований на розв'язання навчальних завдань. Досить часто його використовують у сучасній школі. Дітям подобається готувати та презентувати свої проекти. 
Наступним ефективним методом навчання є «портфоліо». Це складний метод для дітей, оскільки потребує певного часу, щоб зібрати навчальну інформацію та оформити ії самостійно. Портфоліо доцільно застосовувати для оцінювання навчальних досягнень учнів по завершенню семестру.

Ще однією дієвою формою навчання виступає кооперативне навчання (cooperative learning) - учні спільно працюють над досягненням загальної мети в складі малих груп. При цьому мета повинна бути чітко сформульована, завдання - мати структурований характер, а група - бути достатньо малою, щоб кожен учасник мав можливість брати активну участь у спільній роботі. В організації кооперативного навчання можна виокремити навчання у команді (student team learning) та спільне навчання (learning together). Кооперативне навчання передбачає роботу 4-5 осіб над запитаннями, які потрібно розв'язати. Учні спільно формулюють завдання, розподіляють роботу та ресурси між собою. Кожен самостійно виконує свої обов'язки, але оцінюється уся група одночасно. Водночас, наявна індивідуальна відповідальність кожного за виконання конкретного завдання. Методи кооперативного навчання сприяють формуванню у класі позитивної атмосфери, дають змогу з легкістю працювати та вивчати новий матеріал, справляють ефективний вплив на самооцінку учнів, рівень їх досягнень та цікавості до вивчення англійської мови.

Цікавим методом навчання у старших класах $\epsilon$ мікронавчання (microteaching). Учневі дається можливість 5-7 хвилин пояснити класу навчальний матеріал чи завдання у своїй інтерпретації. Для цього учень обирає одне 3 умінь та навичок навчання (навички активізації i стимулювання інтересу учнів; уміння організовувати опитування; вміння подавати новий матеріал; уміння використовувати приклади на уроці; вміння сформувати в учнів потрібні навички), готує урок на 3-5 хвилин, демонструє і проводить його у класі. При цьому здійснюється його відеозапис. Потім клас разом з вчителем обговорюють урок, який записано, щоб визначити рівень засвоєння учнем обраного ним уміння.

Рольова гра (role-playing) - активний метод навчання, за допомогою якого цілеспрямована організована діяльність учнів здійснюється за спеціально розробленим сценарієм і правилами, моделювання в реальних обставинах. Діалог між учасниками рольової гри може бути спонтанним. Рольова гра сприяє кращому розумінню почуттів інших людей і стосунків між ними. Цікавим різновидом рольової гри є обмін думками (rolereversal). Учасники рольової гри обмінюються ролями з метою кращого розуміння мотивів поведінки та почуттів іншої сторони. Аналіз, що проводиться після гри, виявляє труднощі, які відчували учасники, 
причини їх поведінки, а також залежність їх почуттів від поведінки інших учасників.

Сучасні технології відкривають нові можливості для вивчення англійської мови в школі: проекти реалізуються в електронному вигляді; лекції можуть мати форми телелекцій та телеконференцій; на дистанційному навчанні учні спостерігають чи беруть участь у режимі online шкільний урок. Правильне використання методів навчання на уроці ефективно розвиває пам'ять та мислення, формує комунікативну компетентність, дає змогу більш раціонально засвоїти навчальний матеріал, сформувати навички групової роботи. Використовуючи дані методи навчання вчитель може проаналізувати та оцінити рівень засвоєння навчального матеріалу дітьми, виділити сильні та слабкі сторони учнів. За зразками письмових, творчих і контрольних робіт, конспектів школярів виявити їх відповідність віковим особливостям, рівень їх інтелектуального та психологічного розвитку.

При виборі методів навчання вчитель відображає своє бачення мови та широту свої знань, які він хоче передати на уроці. Вибрати сукупність граматичних конструкцій, лексеми чи кілька сталих виразів і 3 ними працювати - вибір за ним. У пошуках ідеального методу навчання необхідно враховувати особливості сприйняття інформації дітьми. Під час уроку використовувати велику кількість різних видів роботи: індивідуальну, парну, групову, колективну. Приділяти достатню увагу подоланню мовного бар'єру, написанню творчих робіт, публічній презентації проектів; аутентичній бесіді; атестації та оцінюванню знань за допомогою «портфоліо»; дискусіям, обговоренню «кейсів»; кооперованому навчанню та ін. Щоб досягти максимальної ефективності у вивченні англійської мови, різні види роботи мають часто змінюватись. Лише за таких умов можна ефективно сприяти формуванню навичок і вмінь, створенню атмосфери співробітництва та виробленню власних цінностей дітей у сучасній школі.

\section{Література:}

1. Балицкая И.В. Интерактивные методы обучение и воспитание в системе образование США: монография / И. В. Балицкая. ЮжноСахалинск: Издательство Сахалинского ГУ, 2004. 107 с.

2. Бичківська Т. М. Використання інтерактивних методів навчання у процесі формування комунікативної компетенції учнів на уроках англійської мови. Наукові записки Національного університету "Острозька академія". 2017. Вип. 64. Ч. 1. С. 48-52. 
3. Пометун О. І., Пироженко Л. В. Сучасний урок. Інтерактивні технології навчання: науково-методичний посібник / О. I. Пометун, Л. В. Пироженко; за ред. О. І. Пометун. Київ, 2004. 192 с.

4. Редько В. Інтерактивні технології навчання іноземної мови. Рідна школа. 2011. № 8-9. С. 28-36.

5. Шевченко Є. Використання інтерактивних технологій для розвитку пізнавального інтересу на уроках англійської мови. Англійська мова та література. 2005. № 24. С. 4-6.

DOI https://doi.org/10.30525/978-9934-26-180-0-54

\title{
ТЕСТОВИЙ КОНТРОЛЬ АУДИТИВНИХ УМІНЬ СТУДЕНТІВ НЕМОВНИХ СПЕЦІАЛЬНОСТЕЙ ЗВО У ПРОЦЕСІ ВИВЧЕННЯ ДИСЦИПЛІНИ «ІНОЗЕМНА МОВА (ЗА ПРОФЕСІЙНИМ СПРЯМУВАННЯМ»)
}

\author{
Черчата Л. М. \\ кандидат педагогічних наук, \\ доиент кафедри загального і слов'янського мовознавства \\ та іноземних мов \\ Полтавський національний педагогічний університет \\ імені В. Г. Короленка \\ м. Полтава, Украӥна
}

Аудіювання - це складний активний процес мовленнєвої діяльності, що потребує детального вивчення як 3 точки зору функціонування механізмів сприйняття, так і розвитку аудитивних умінь та навичок. Практичне володіння іноземною мовою, а надто англійською як мовою міжнародного спілкування $\epsilon$ викликом сьогодення. Цього потребує інтеграція України у міжнародний освітній простір із необмеженими можливостями навчатися в університетах закордоння й епоха сучасних технологій. Тому значення аудіювання як виду мовленнєвої діяльності посутньо зростає. Вміння розуміти сприйняте на слух усне мовлення набуває більшої значущості, оскільки воно сприяє формуванню низки компетенцій, як-от: міжкультурної, інформаційної чи то професійної. Тож актуальність навчання аудіювання постає незаперечною. До того ж його визнають одним із ефективних засобів розвитку комунікативних навичок, а сформована аудитивна компетенція $є$ важливим складником професійної 